\title{
Effect of Oligofructose-enriched Inulin on Bone Metabolism in Girls with Low Calcium Intakes
}

\author{
Maria Cristina Corrêa de Souza ${ }^{1,4}$, Franco Maria Lajolo ${ }^{1}$, Ligia de Araujo Martini ${ }^{2}$, Nelton \\ Bespalez Correa $^{3}$, Milana Cara Dan ${ }^{1}$ and Elizabete Wenzel de Menezes ${ }^{1:}$ \\ ${ }^{1}$ Laboratório de Química; Bioquímica e Biologia Molecular de Alimentos; Faculdade de Ciências Farmacêuticas; \\ Universidade de São Paulo; Av. Prof. Lineu Prestes, 580; Bloco 14; 05508-900; São Paulo - SP - Brasil. \\ ${ }^{2}$ Departamento de Nutrição; Faculdade de Saúde Pública; Universidade de São Paulo; São Paulo - SP - Brasil. \\ ${ }^{3}$ Universidade Paranaense; Umuarama - PR - Brasil. ${ }^{4}$ Universidade Federal da Grande Dourados; Dourados - MS \\ - Brasil
}

\begin{abstract}
In the present clinical study, the effect of oligofructose-enriched inulin was studied on bone metabolism in girls from 9 to 12 years old, with low habitual calcium intakes, who attended public schools. Two calcium-enriched formulations, supplemented with oligofructose-enriched inulin (test drink) or without (standard drink) were made. Sixty pre-pubertal girls were randomized into a double-blind and crossover design, divided into three groups and received one daily portion of either the standard drink (group 1) or test drink (group 2) during 11 weeks, followed by a three-week washout period. Group control did not receive any supplementation. Biochemical evaluations of serum calcium, intact parathyroid hormone - iPTH - and bone alkaline phosphatase - BAP - were performed at baseline and after 4, 8 and 11 weeks of each intervention period. In group 1, a significant increase in serum calcium and BAP and a reduction of $i P T H$ were observed after consumption of the test drink.
\end{abstract}

Key words: Oligofructose-enriched inulin, calcium intakes, bone markers, prepubertal girls, prebiotics, bone and mineral metabolism

\section{INTRODUCTION}

Calcium is the most abundant mineral in the body and is most present (approximately 99\%) in bones and teeth. Only $1 \%$ is found in blood, extra cellular liquid and inside cells of soft tissue, where it regulates important metabolic functions (Ilich and Kerstetter, 2000). The peak of bone mass acquisition occurs until the third decade of life, and it is dependent on dietary calcium, which affects bone mineralization reserves and subsequent osteoporosis risk (Heaney, 2001a). It is, therefore, not surprising that calcium is the most studied nutrient with respect to bone health (Ilich and Kerstetter, 2000) and that high calcium intakes are considered as strategy in the prevention of osteoporosis. Nonetheless, food consumption patterns during adolescence clearly show that calcium intakes are often inadequate (Albano and Souza, 2001), especially in developing countries such as Brazil (Lerner et al., 2000; Johnson-Down et al., 2003). Therefore, strategies to improve the absorption of calcium from the diet are considered important.

\footnotetext{
*Author for correspondence: wenzelde@usp.br
} 
Prebiotics are non-digestible food ingredients that selectively stimulate the growth and/or activity of a limited number of beneficial bacteria in the colon (mainly bifidobacteria and lactobacilli), thereby improving the host's health. Inulin and oligofructose are prebiotic food ingredients that are naturally extracted from the chicory root (Chicorium intybus) (Roberfroid, 2007) and can also be found in plants originally from the Brazilian tropical savanna (cerrado), such as the families Vernoniae and Asteraceae (Hayashi and Appezzato-da-Glória, 2007). Intervention trials in adolescents with adequate calcium intakes have demonstrated a significant increase in calcium absorption and bone mineralization (bone mineral density and content) after supplementation with oligofructose-enriched inulin (8 g/d of Synergy 1$)$ (Griffin et al., 2002; Griffin et al., 2003; Abrams et al., 2005; Holloway et al., 2007). However, literature does not present data on populations with low calcium intakes.

Bone development can be evaluated by bone biomarkers of formation and reabsorption. The use of these parameters has been increasing due to their low risk and reduced time of experiments. Formation markers measure products as a result of the osteoblast action, while reabsorption markers measure the osteoclast action, main cellular type involved on the reabsorption of bone matrix (Calvo et al., 1996; Vieira, 2000). Among formation markers, bone alkaline phosphatase (BAP) is commonly used and reflects the osteoblast activity and number related mainly to bone mineralization (Arnett and Henderson, 1998). Clinical assays evaluating biomarkers of bone metabolism have been carried with the male and female children and adolescents; however, this evaluation must be done carefully once their indexes are superior than the adult ones, due to children's growth. These assays are advantageous in short-period interventions, differently from bone densitometry that requests an approximate time of 12 months (Vieira, 2007) and implicates in lower and higher cost. A way of avoiding an error in the interpretation of data is the evaluation of a control group, which allows the researcher to verify the growth in the studied period.

The objective of the present clinical study was to evaluate the effect of oligofructose-enriched inulin, supplemented to a milk-based drink, on bone metabolism in girls aged 9 to 12 years, with low habitual calcium intakes.

\section{MATERIALS AND METHODS}

\section{Subjects}

Sixty girls aged between 9.0 and 11.9 years old were selected among the healthy students of public schools in Umuarama (PR, Brazil). The volunteers were first interviewed by a dietitian, and calcium intakes were estimated using three 24-h food recalls (R24h). Only girls with habitual mean calcium intake of $500 \mathrm{mg} / \mathrm{d}$ and Tanner pubertal stage of 2 or 3 (breast) (Tanner, 1962) were considered eligible for the study.

Girls were excluded from the study if they were postmenarcheal, received hormonal (including contraceptives) or corticosteroid therapy, vitamin or mineral supplementation, had kidney or gastrointestinal diseases, hyperparathyroidism, changes in bone metabolism or rheumatic diseases, tobacco addiction, pregnancy or breast feeding, or if they had $\mathrm{BMI}<5^{\circ}$ or $>95^{\circ}$ percentile for sex and age (Bray, 1989).

\section{Dietary records}

Individuals eligible for the study were randomly divided into three groups with twenty participants in each group. The volunteers were evaluated in terms of food consumption and life style at baseline and at the end of the experiment. At the beginning of the study, 24-h food recalls (R24h) were taken for three days (including one weekend day), whereas at the end of the study, it included only one day. The American Food Composition Table (USDA, 2005) was used to estimate daily calcium intakes. Fructan intakes were estimated from published data (Van Loo et al., 1995; Paschoal, 2007).

\section{Milk-based drinks}

Two dry mixtures (standard and test) were used to prepare the non-fermented milks, both enriched with $200 \mathrm{mg}$ calcium (per $200 \mathrm{ml}$ of milk). The test drink was supplemented with $8 \mathrm{~g}$ oligofructose-enriched inulin (Beneo ${ }^{\mathrm{TM}}$ Synergy1, ORAFTI, Tienen, Belgium) (per $200 \mathrm{ml}$ of milk). Drink formulations were prepared by Boa Safra Alimentos from Curitiba (PR, Brazil). General and sensory acceptances of the drinks were evaluated by a 7-point facial hedonic scale. This test is used to evaluate the preferences and/or acceptance of products for infants and children whose facial expressions easily tell their individual reactions to 
a product. Each group of examiners was formed by fifty girls, aged between 9 and 12 years old, not trained, and selected randomly in four public schools in the city of Umuarama (PR, Brazil), and who had not taken part in the clinical assay.

Analysis of the drinks were done for the moisture, ash, lipids (Instituto Adolfo Lutz, 1985) and protein (AOAC, 1995). Fructans were analyzed by HPLC-PAD (Hoebregs, 1997). Total and fecal coliforms, yeast and mould, total mesophiles and Salmonella scores were evaluated for the microbiological characterization of the samples (LANARA, 1981).

\section{Study design}

Sixty pre-pubertal girls with low habitual calcium intakes were randomly divided into three groups. Volunteers participating in the double-blind study were randomized into two groups (crossover design) with two 11-week intervention periods and a between-in washout of three weeks. Group 1 received the standard milk-based drink during the first intervention and the test milk-based drink during the second intervention. Subjects in group 2 received both interventions in reversed order. Subjects in group 3 (control group) did not receive any of the drinks and were asked to keep their habitual feeding and lifestyle. The implementation of a control group, receiving no supplementation, was considered necessary for the study once individuals at this age and maturation stage have various metabolic alterations and to which a comparison could be made. The presence of intestinal uncomforts such as diarrhea or flatulence, due to the prebiotic supplementation, was checked.

Blood samples were taken at the Clinical Analysis Laboratory of the Universidade Paranaense from Umuarama (PR, Brazil) in the morning after an eight-hour fasting period. Blood was taken at baseline, and after 4, 8 and 11 weeks of each intervention period, totalizing eight samples per subject. These four evaluations aimed to test the sensibility of the biomarker used in shorter periods. All the analysis were performed in duplicate and included serum concentrations of calcium (Calcium Liquiform-Labtest Diagnostic kit); bone alkaline phosphatase (BAP) (Metra Biosystem Inc., Alkaphas-B kit, Mountain View, CA. USA); and intact parathyroid hormone (iPTH) (Roche Diagnostics). The intra and inter variation coefficients of the analysis were 0.78 and 1.07 for serum calcium, 5.8 and 7.6 for BAP and 2.0 and 3.4 for iPTH, respectively.

\section{Statistical analysis}

The effect of treatment on bone metabolism between the groups and sampling times according to the weeks of study was assessed by ANOVA repeated measures test. In order to make the comparisons among times, the Profile test by contrasts was used. Tukey's post-hoc test was used for between-group comparisons. For describing the profile of the sample, tables of frequency of categorical variables and descriptive statistics with position measures and dispersion of continuous variables were prepared. Pearson's chi-square test was used to compare the categorical variables among the groups, or Fisher's exact test was used when necessary. Kruskal-Wallis or Mann-Whitney test for variables without normal distribution were used to compare the numerical variables among the groups. In order to make the correlation analysis of the area under the curve (AUC) and area under the incremental curve (AUIC), Spearman's correlation coefficient was used. Statistical analysis was carried out using The Statistical Analysis Systems software version 8.02 (SAS Institute, Cary, NC, USA). Results were considered statistically significant when $\mathrm{P}<0.05$.

\section{Ethical considerations}

The protocol (no 210) was submitted and approved by the Ethical Research Committee of the School of Pharmaceutical Science of the University of Sao Paulo (Brazil). Parents or legal guardians were informed of the study and a signed consent form was requested.

\section{RESULTS}

\section{Product characterization and sensorial evaluation}

The standard and test milk-based drinks were similar in composition, except for the fructan content. The daily $200 \mathrm{ml}$ portion of the test milky drink served to children during the intervention presented a concentration of $8 \mathrm{~g}$ of fructans and $202.15 \pm 12.13 \mathrm{mg}$ of calcium and the standard milky drink presented $205.28 \pm 15.08 \mathrm{mg}$ of calcium. The ash contents of the test and the standard milky drinks, in the $200 \mathrm{ml}$ portion, were 2.03 and $2.50 \mathrm{~g}$, lipids 4.82 and $4.12 \mathrm{~g}$, protein 
9.59 and $8.97 \mathrm{~g}$, and carbohydrates 32.40 and $32.50 \mathrm{~g}$, respectively. Microbiological analysis confirmed the absence of any of the organisms studied. Sensorial analysis indicated no differences between standard and test milk-based drinks.

\section{Subject characteristics and biochemical parameters at baseline}

Fifty-three out of the sixty recruited volunteers completed the study. Discontinuation was due to move (four subjects), rejection of blood sampling (one subject), or dissatisfaction with the draft design (two subjects in the control group). The mean BMI of the subjects was $18 \mathrm{~kg} / \mathrm{m}^{2}$. Mean calcium intakes were approximately $500 \mathrm{mg} / \mathrm{d}$, and much lower than the AI for this age group (1300 $\mathrm{mg} / \mathrm{d}$ ). There were no significant differences in BMI and calcium intakes among the studied groups (Kruskal-Wallis test).When the results of ANOVA for repeated measures were evaluated, in order to compare BMI and calcium intake among the groups and the sampling times according to the weeks of study, no significant statistical differences between the initial and final times occurred, neither on the interaction between the groups and sampling times. The similar intake of calcium between initial and final times showed the maintenance of food intake habits of the participants during the clinical assay. The mean daily intake of fructans among the volunteers was $7.09 \pm 3.7 \mathrm{~g}$.

The subjects' life style did not differ among the groups and remained the same during the course of the study; 81 to $94 \%$ of the subjects were white; 65 to $90 \%$ of the subjects had regular physical activity (2-4 d/week). Approximately $80 \%$ of the girls had regular sun exposure (2 times/week, about 1 to $2 \mathrm{~h} / \mathrm{d}$ ). Stool frequency of the subjects remained constant along the study (except for one in group 2). Three girls (5\%) of group 2 reported flatulence during the first 3 to 4 days of the intervention. None of the volunteers discontinued participation because of symptoms. Biochemical parameters in bone metabolism at baseline of the two intervention periods were not different among the participants (Table 1), which demonstrated a similarity of the participants of the three study groups, including the control group.

Table 1 - Biochemical parameters evaluated at baseline of the two intervention periods of the clinical study.

\begin{tabular}{cccccc}
\hline \multicolumn{2}{c}{$\begin{array}{c}\text { Group/Biochemichal } \\
\text { parameter }\end{array}$} & Group 1 (n=18) & Group 2 $(\mathbf{n = 1 7 )}$ & $\begin{array}{c}\text { Control Group } \\
(\mathbf{n = 1 8})\end{array}$ & Tukey test \\
\hline \multirow{2}{*}{ Calcium $(\mathrm{mg} / \mathrm{dl})$} & $1^{\text {st }}$ period & $9.94 \pm 0.81$ & $9.40 \pm 0.83$ & $9.27 \pm 0.66$ & $\mathrm{NS}$ \\
& $2^{\text {nd }}$ period & $9.06 \pm 0.54$ & $8.99 \pm 0.43$ & $8.93 \pm 0.46$ & $\mathrm{NS}$ \\
$\mathrm{BAP}(\mathrm{U} / \mathrm{l})$ & $1^{\text {st }}$ period & $124.33 \pm 21.56$ & $107.88 \pm 20.07$ & $113.00 \pm 24.30$ & $\mathrm{NS}$ \\
& $2^{\text {nd }}$ period & $128.22 \pm 22.60$ & $117.65 \pm 22.65$ & $120.44 \pm 26.92$ & $\mathrm{NS}$ \\
$\mathrm{iPTH}(\mathrm{pg} / \mathrm{ml})$ & $1^{\text {st }}$ period & $22.91 \pm 8.29$ & $18.95 \pm 6.86$ & $21.63 \pm 8.22$ & $\mathrm{NS}$ \\
& $2^{\text {nd }}$ period & $19.13 \pm 7.46$ & $20.91 \pm 8.50$ & $18.93 \pm 8.64$ & $\mathrm{NS}$ \\
\hline
\end{tabular}

BAP, bone alkaline phoshatase; iPTH, intact parathyroid hormone; NS, not significant $(P \geq 0.05)$; Values are means \pm SD.

\section{Crossover study}

Figure 1 shows the mean concentrations of serum calcium at sampling times according to the weeks of study and per group. In group 1, calcium levels were significantly higher during the test drink intervention at the 18th and 22nd weeks of supplementation when compared to the standard drink (respectively $\mathrm{P}=0.005$ and $\mathrm{P}<0.001$ ).

When the bone alkaline phosphatase (BAP) was compared at sampling times according to the weeks of study and per group (Fig. 1), there was a significant increase at the 18th week for both groups and at the 8th and 22nd weeks for group 1 $(\mathrm{P}<0.001)$. Concentrations of intact parathyroid hormone at sampling times according to the weeks of study and per group are presented in Figure 1. There was a significant reduction at the 4 th week only in group 1 and at the 18th and 22nd weeks in both groups $(\mathrm{P}<0.001)$. 

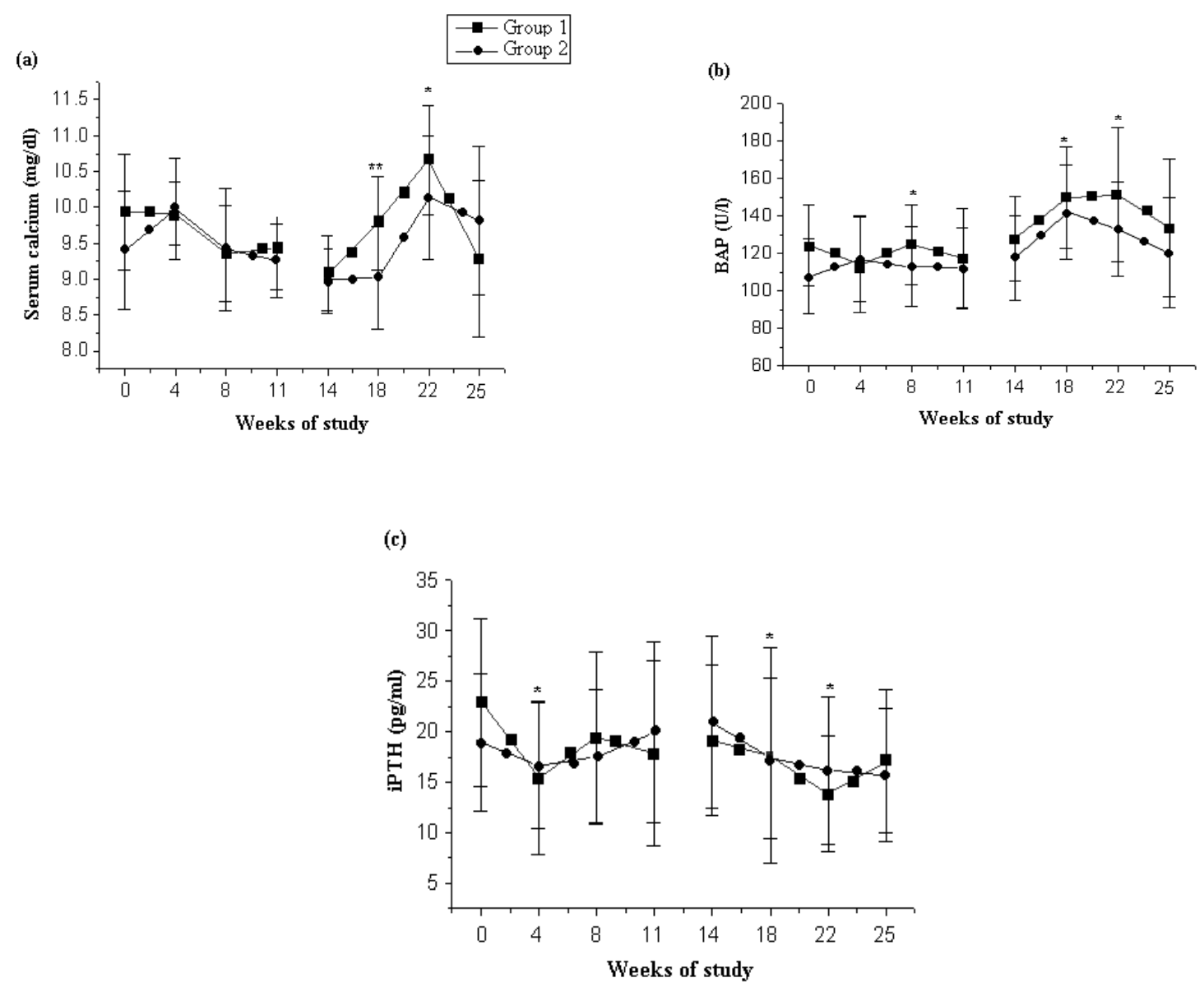

Figure 1 - Mean serum calcium concentrations (mg/dl) (a), bone alkaline phosphatase (BAP) (U/l) (b) and intact parathyroid hormone (iPTH) (pg/ml) (c) for group 1 (1st intervention (weeks 0-11): standard drink and 2nd intervention (weeks 14-25): test drink) and group 2 (1st intervention (weeks 0-11): test drink and 2nd intervention (weeks 14-25): standard drink); * significant difference among the times of sampling according to the weeks of study (Profile test); ** significant difference between groups (Tukey test).

The results of ANOVA for repeated measures for the crossover study are presented in Table 2. It was observed that the carryover effect did not present significant statistical difference for any of the biochemical parameters (Table 2), showing that a 3-week washout period was enough to eliminate the residual effects of the administered formulation and it did not persist when crossing the experimental periods. It was also possible to observe that fructans did not show cumulative effect on the organism. In this kind of experiment, it is important to separate residual effects from treatment effects. Sampling times according to the weeks of study showed significant differences for all the evaluated biochemical parameters (Table 2 ), which could be observed in Figure 1. When the treatment-exclusive effect was evaluated, there was a significant difference between the treatment with the standard drink and the treatment with the test drinks for BAP (Table 2). When the interaction between the treatment and intervention period was studied, again BAP presented a significant difference between both the treatments per intervention period (1st and 2 nd periods) (Table 2). 
Table 2 - Statistical data of the effects of standard and test drinks on biochemical parameters in the crossover study.

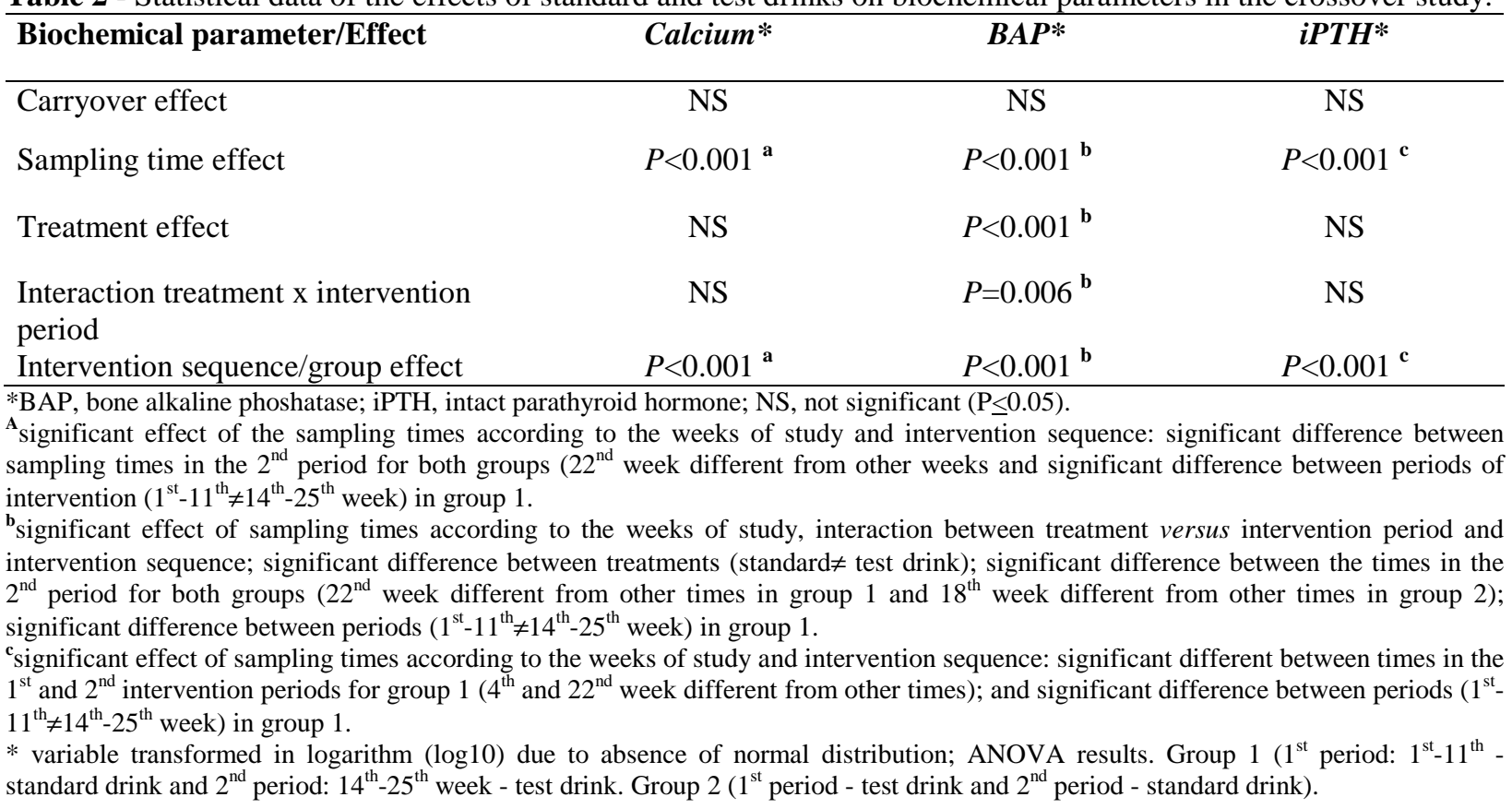

In the study of intervention sequence effect per group, a significant difference was observed in serum calcium, BAP and iPTH (Table 2). Serum calcium showed a significant increase in the $2^{\text {nd }}$ period compared to the $1^{\text {st }}$ period in group $1\left(1^{\text {st }}\right.$ period - standard drink and $2^{\text {nd }}$ period - test drink). BAP showed a significant increase in the $2^{\text {nd }}$ period (supplementation with test drink) compared to the $1^{\text {st }}$ period in group 1. iPTH showed a significant reduction in the $2^{\text {nd }}$ period compared to the $1^{\text {st }}$ period in group 1 , when the treatment sequence was considered $\left(1^{\text {st }}\right.$ period standard drink and $2^{\text {nd }}$ period - test drink). The following significant results for the variables were found for group 1: serum calcium and bone alkaline phosphatase increased in the $2^{\text {nd }}$ period (supplementation with test drink); intact parathyroid hormone decreased in the $2^{\text {nd }}$ period (supplementation with test drink).

Once the studied population could present hyperparathyroidism due to inadequate calcium intake, the correlation between the serum calcium and intact parathyroid hormone was analyzed. Therefore, the area under incremental curve (AUIC), which corresponded to a profile of the parameters measured along the times, was evaluated. The Spearman correlation was used, once the data did not present a normal distribution. A significant negative correlation $(r=-0.609$;
$\mathrm{P}=0.009)$ was observed between the measured evolutions (AUIC) of serum calcium and $\mathrm{PPTH}$ in group 2, in the second experimental period, that is, the increase of serum calcium related to the higher fall of iPTH.

\section{DISCUSSION}

In the present study, children were enrolled in public schools and presented very low mean calcium intakes. Such low calcium intakes in students living in Sao Paulo were observed before by Lerner et al. (2000), who observed a mean calcium intake for both the males and females of about $50 \%$ of the recommended level. Participants in economically better areas presented higher daily intakes $(630 \pm 324 \mathrm{mg})$ compared to the participants of lower incomes $(524 \pm 298 \mathrm{mg})$. The latter was close to the mean of the present study group $(500 \mathrm{mg} / \mathrm{d})$. Although the evidence of the positive impact of adequate calcium intakes on bone metabolism was clear, inadequate calcium intakes commonly occurred (Ilich and Kerstetter, 2000).

The present study used a crossover design, where each patient received the two kinds of treatment, and the order of supplementation was the only variation. In this kind of experimental design, each 
volunteer is his/her own control, which avoids confusions in relation to the analysis of results, mainly at this age when there is intense growth.

Results showed that the supplementation of 200 $\mathrm{mg} / \mathrm{d}$ of calcium, prior to supplementation with oligofructose-enriched inulin, improved the plasma calcium level, possibly increased the bone formation (as indicated by the increase in BAP, which demonstrated higher bone metabolic activity) and reduced iPTH. These effects were not observed with calcium supplementation alone. The effect of the oligofructose-enriched inulin could be ascribed to the higher proportion of absorption of the supplemental calcium, as observed in other studies (Griffin et al., 2002; 2003; Abrams et al., 2004; 2005). Biochemical markers of bone metabolism were measured in the present study because of the shorter time of intervention necessary to evaluate them. Children in their growth phase (9 to 12 years) have a bone remodeling period that takes a few weeks (Heaney, 2001b), which allows to estimate the effect of dietary intervention strategies on markers of bone metabolism in a limited time period. Indeed, the efficiency of measuring bone metabolism biomarkers has been demonstrated (van Coeverden et al., 2002). Studies in diverse animal models have shown the beneficial effect of inulin and oligofructose in the colonic epithelium, stimulating proliferation in the crypts, increasing the concentration of polyamines, changing the profile of mucins and modulating endocrine as well as immune functions (Roberfroid, 2005; Budiño et al., 2005), and on calcium absorption and bone mass (Roberfroid, 2002; Scholz-Ahrens et al., 2002; Cashman, 2003; Kruger et al., 2003; Lobo et al., 2006). This was also observed in adolescents (Griffin et al., 2002), showing a significant increase in calcium absorption with oligofructose-enriched inulin supplementation $(8$ $\mathrm{g} / \mathrm{d}$ of Synergy1). In a subsequent study, the authors observed that those individuals with lower baseline calcium absorption had a higher response to supplementation with oligofructose-enriched inulin (8 g/d of Synergy1) (Griffin et al., 2003). However, in these last two studies, mean calcium intake was close to the adequate one, presenting $1510 \pm 255 \mathrm{mg} / \mathrm{d}$ in the first study, and $1140 \pm 650$ $\mathrm{mg} / \mathrm{d}$ in the second study.

Another study (Abrams et al., 2005) observed that a long-term supplementation with oligofructoseenriched inulin ( $8 \mathrm{~g} / \mathrm{d}$ of Synergy 1 ) increased bone mineral density and content significantly in adolescents, indicating that the higher percentage of absorbed calcium was accreted by the bone. This was observed through the comparison with the control group, which received placebo during the period, demonstrating that the result was not due to the growth of the studied group. According to the authors, the magnitude of the benefit depends on genetic alterations in calcium absorption due to an interaction between the Fok 1 gene, presenting three polymorphic types (FF, Ff and ff), and the response of each of them to the oligofructose-enriched inulin.

Furthermore, there is a supposition that some genotypes may be more benefited by the daily intake of fructans, and also because of individual variations in fructan intakes. People with low fructan intakes may present a reduced calcium absorption, but a good response to Beneo ${ }^{\mathrm{TM}}$ Synergy1, and people with high intake of fructans may have better calcium absorption, but a poorer response to Beneo ${ }^{\mathrm{TM}}$ Synergy1 (Griffin et al., 2003). The high fructan intakes in this Brazilian population $(7.09 \pm 3.7 \mathrm{~g} / \mathrm{d}) \mathrm{might}$, however, have minimized the effect of inulin-type supplementation.

In a recent study, Abrams et al. (2004) observed an increase in calcium absorption in the girls with low calcium intakes (63.4\%), compared to the girls with adequate calcium intakes (44.9\%). That is positive, but absorption generally does not exceed 60 to $70 \%$ even in adolescents (Food and Nutrition Board, 1997). The authors observed an absorption adaptation at a very low intake $(386 \mathrm{mg} / \mathrm{d})$. However, when calcium balance was evaluated, it remained lower in the group with reduced calcium intakes. This suggested that, during the present experiment, even though the participants did not have their calcium absorption evaluated and also presented reduced calcium intakes and possibly a high mineral absorption, there was a partial improvement in calcium absorption, specially when consumed together with fructan, possibly to soften calcium state, which was not adequate, and interfered in the bone metabolism, demonstrated by the increase in serum calcium and BAP and the decrease in $\mathrm{iPTH}$. This pointed the necessity of future studies with populations that have low calcium intakes in order to evaluate calcium absorption and bone mass.

One of the factors that determines thefracture resistance at adult age is the quantity of bone mass that was gained during the growth (Borges and Brandão, 2006), which demonstrates the 
importance of this kind of study in children and adolescents.

Frazão and Naveira (2006), in a review of studies about the prevalence of osteoporosis in Brazil, observed a small number of studies and the necessity of implementing projects mainly in developed regions of the country aiming to use prevalence data in public health projects. A great part of the population, especially the females in Brazil, was at risk of reduced mass gain and low bone mineralization during adolescence caused by deficient calcium intake. Adequate prevention strategies, therefore, needed to be urgently implemented. Among these, there is the consumption of foods that are sources of calcium, foods fortified with calcium or foods with increased bioavailability. The results of this study indicated the potential of supplementing the daily diet with oligofructose-enriched inulin to improve the bone metabolism in adolescent girls.

To conclude, the present study indicated that the supplementation of a calcium-enriched $(200 \mathrm{mg} / 200 \mathrm{ml})$ milk-based drink with oligofructose-enriched inulin $\left(8 \mathrm{~g} / \mathrm{d}\right.$ of Beneo ${ }^{\mathrm{TM}}$ Synergy1) to the diet of prepubertal girls (with low habitual calcium intake) was well tolerated and beneficially altered markers of bone metabolism. This was shown by a higher bone formation (increase in BAP) and serum calcium levels and a decrease in iPTH. The effect of oligofructoseenriched inulin appeared after an 11-week calcium supplementation period and it indicated a possible dependence on food calcium concentration for the subjects with low calcium intakes. The beneficial effect of oligofructose-enriched inulin on calcium metabolism could help adolescents to reach their peak of bone mass acquisition.

\section{ACKNOWLEDGEMENTS}

The authors acknowledge PRONUT-Post Graduation Course - FCF/FEA/FSP-USP; ORAFTI Active Food Ingredients (Tienen, Belgium), for sponsoring the research; Clariant Brasil, for providing ingredient for the milk-based drinks; Boa Safra Alimentos, for providing ingredients, preparing and packing the milk-based drinks; Universidade Paranaense and the City Hall of Umuarama (PR, Brazil), for providing the infrastructure to conduct the clinical studies; the Nutrition students of Universidade Paranaense, for distributing the products to the volunteers and for their help with data collection; and ultimately, the volunteers, for their dedication and collaboration.

\section{RESUMO}

No presente ensaio clínico, o efeito de oligofrutose enriquecida com inulina foi estudado no metabolismo ósseo de meninas de 9 a 12 anos com baixa ingestão habitual de cálcio, matriculadas em escolas públicas. Duas formulações foram suplementadas ou não (bebida padrão) com oligofrutose enriquecida com inulina (bebida teste). Sessenta meninas pré-púberes foram aleatorizadas em estudo duplo cego crossover e divididas em três grupos e receberam uma porção diária da bebida padrão (grupo 1) ou teste (grupo 2) durante 11 semanas, seguidos por um período de intervalo de três semanas. O grupo controle não recebeu nenhuma suplementação. As avaliações bioquímicas de cálcio sérico, paratormônio intacto - PTHi e fosfatase alcalina fração óssea - FAO foram executadas ao início e após 4,8 e 11 semanas de cada período de intervenção. No grupo 1, um aumento significante no cálcio sérico e FAO e uma redução no PTHi foram observadas após o consumo da bebida teste.

\section{REFERENCES}

Abrams, A.S.; Griffin, I.J.; Hawthorne, K.M.; Liang, L.; Gunn, S.K.; Darlington, G.; Ellis, K.J. (2005), A combination of prebiotic short- and long-chain inulintype fructans enhances calcium absorption and bone mineralization in young adolescents. Am. J. Clin. Nutr., 82, 471-476.

Abrams, A.S.; Griffin, I.J.; Hicks, P.D.; Gunn, S.K. (2004), Pubertal girls only partially adapt to low dietary calcium intakes. J. Bone Min. Research, 19, 759-763.

Albano, R.D.; Souza, S.B. (2001), Ingestão de energia e nutrientes por adolescentes de uma escola pública. $J$. Pediatr., 77, 512-516.

Arnett, T.R.; Henderson, B. (1998), Methods in bone biology, 1st ed., London: Chapman and Hall.

Association of Official Analytical Chemists (1995), Official methods of Analysis, 16th ed., v.2. Washington DC: AOAC.

Borges, J.L.C.; Brandão, C.M.A. (2006), Low bone mass in children and adolescents. Arq. Bras. End. Metab., 50, 775-82.

Bray, H. (1989), Classification and evaluation of the obesities. Med. Clin. North Amer., 73, 161-184. 
Budiño, F.E.L.; Thomaz, M.C.; Kronka, R.N.; Nakaghi, L.S.O.; Tucci, F.M.; Fraga, A.L.; Scandolera, A.J.; Huaynate, R.A.R. (2005), Effect of probiotic and prebiotic inclusion in weaned piglet diets on structure and ultra-structure of small intestine. Braz. Arch. Biol. Tech., 48, 921-929.

Calvo, M.S.; Eyre, D.R.; Gundberg, C.M. (1996), Molecular basis and clinical application of biological markers of bone turnover. Endoc. Reviews, 17, 333368.

Cashman, K. (2003), Prebiotics and calcium bioavaibility. Curr. Iss. Intest. Microbiol., 4, 21-32.

van Coeverden, S.C.C.M.; Netelenbos, J.C.; Ridder, C.M.; Ross, J.C.; Popp-Snijders, C.; Waal, H. (2002), Bone metabolism markers and bone mass in healthy pubertal boys and girls. Clin. Endocrin., 57, 107-116.

Food and Nutrition Board (1997), Dietary Reference Intake: applications in dietary assessment. Washington D.C.: National Academic Press.

Frazão, P.; Naveira, M. (2006), Prevalência de osteoporose: uma revisão crítica. Rev. Bras. Epidemiol., 9, 206-214.

Griffin, I.J.; Davila, P.M.; Abrams, A.S. (2002), Nondigestible oligosaccharides and calcium absorption in girls with adequate calcium intake. Brit. J. Nutr., 87, Suppl. 2, S187-191.

Griffin, I.J.; Hicks, P.M.D.; Heaney, R.P.; Abrams, S.A. (2003), Enriched chicory inulin increases calcium absorption mainly in girls with lower calcium absorption. Nut. Research, 23, 901-909.

Hayashi, A.H.; Appezzato-da-Glória, B. (2007), Anatomy of the underground system in Vernonia grandiflora Less. and V. brevifolia Less. (Asteraceae). Braz. Arch. Biol. Tech., 50, 979-988.

Heaney, R.P. (2001a), There should be a dietary guideline for calcium. Am. J. Clin. Nutr., 71, 658-61.

Heaney, R.P. (2001b), The bone remodeling transient: interpreting interventions involving bone-related nutrients. Nutr. Reviews, 59, 327-333.

Hoebregs, H. (1997), Fructans in food and food products, ion-exchange chromatoraphic method: Collaborative study. J. AOAC Int., 80, 1029-1037.

Holloway, L.; Moynihan, S.; Abrams, S.A.; Kent, K.; Hsu, A.R.; Friedlander, A.L. (2007), Effect of oligofructose-enriched inulin on intestinal absorption of calcium and magnesium and bone turnover markers in postmenopausal women. Brit. J. Nutr., 97, 365-372.

Ilich, J.Z.; Kerstetter, J.E. (2000), Nutrition in bone health revisited: a story beyond calcium. J. Am. Coll. Nutr., 19, 715-737.

Instituto Adolfo Lutz (1985), Normas analíticas do Instituto Adolfo Lutz. Métodos químicos e físicos para análise de alimentos. 3rd ed., p. 21-25, São Paulo: Inst. Adolfo Lutz.

Johnson-Down, L.; L’Abbé, M.R.; Lee, N.S.; GrayDonald, K.C. (2003), Appropriate calcium fortification of the food suplly presents a chalenge. Am. Soc. Nutr. Sci., 133, 2232-2238.

Kruger, M.C.; Brown, K.E.; Collett, G.; Layton, L.; Schollum, L.M. (2003), The effect of fructooligosaccharides with various degrees of polymerization on calcium bioavaibility in the growing rat. Exp. Biol. Med., 228, 683-688.

LANARA (Laboratório Nacional de Referência Animal) (1981), Métodos analíticos oficiais para controle de produtos de origem animal e seus ingredientes. Brasilia: Ministério da Agricultura, v.1: Métodos Microbiológicos.

Lerner, B.R.; Lei, D.L.M.; Chaves, S.P.; Freire, R.D. (2000), Consumption of calcium by adolescents from public schools em Osasco, São Paulo, Brazil. Rev. Nutr., 13, 57-63.

Lobo, A.R.; Colli, C.; Filisetti, T.M.C.C. (2006), Fructooligosaccharides improve bone mass and biomechanical properties in rats. Nutr. Res., 26, 413420.

Paschoal, G.B. (2007), Fermentabilidade de frutanos da cebola (Allium cepa L): estudo in vivo, in vitro e do efeito trófico no intestino grosso. $\mathrm{PhD}$ Thesis, University of São Paulo, São Paulo, Brazil.

Roberfroid, M. (2002), Functional foods: concepts and application to inulin and olifructose. Brit. J. Nutr., 87, Suppl. 2, S139-143.

Roberfroid, M. (2005), Introducing inulin-type fructans. Brit. J. Nutr., 93, Suppl. 1, S13-25.

Roberfroid, M. (2007), Prebiotics: The concept revisited. J. Nutr., 137, Suppl. 3, 830S-837S.

Scholz-Ahrens, K.E.; Açil, Y.; Schrezenmeier, J. (2002), Effect of oligofructose or dietary calcium on repeated calcium and phosphorus balances, bone mineralization and trabecular structure in ovariectomized rats. Brit. J. Nutr., 88, 365-377.

Tanner, J.M. (1962), Growth at adolescence, 2nd ed. Oxford: Blackwell Scientific Publications.

USDA - U.S. Departament of Agriculture Agricultural Research Service (2005), Nutrient Data Laboratory. http://www.nal.usda.gov/fnic/foodcomp

Van Loo, J.; Coussement, P.; Leenheer, L.D.; Hoebregs, H.; Smits, G. (1995), On the presence of inulin and oligofructose as natural ingredients in the western diet. CRC Crit. Reviews Food Sci. Nutr., 35, 525-552.

Vieira, J.G.H. (2000), Marcadores bioquímicos. In Osteoporose Diagnóstico e Tratamento, 1st ed., p. 197-205 [VL Szejnfeld editor] São Paulo: Sarvier.

Vieira, J.G.H. (2007), Diagnóstico laboratorial e monitoramento das doenças osteometabólicas. $J$. Bras. Patol. Med. Lab., 43, 75-82.

Received: December 03, 2007; Revised: May 26, 2008; Accepted: July 10, 2009. 